\title{
COVID-19 and symbolic action: global pandemic as code, narrative, and cultural performance
}

\author{
Jeffrey C. Alexander ${ }^{1} \cdot$ Philip Smith $^{1}$
}

Published online: 9 October 2020

(c) Springer Nature Limited 2020

Cultural sociology emerges from the paradox that societies today are not nearly as rational as they would like to think they are. A century of Marxist and Weberian social theory has been on a fool's errand: It turns out we are not yet modern. It is precisely because the line between "traditional" and "modern" has turned out to be so problematic that Emile Durkheim's theorizing about the Aboriginal religion still speaks to the cultural processes of our time. Levi-Strauss also looked deeply into the wisdom of so-called primitive society. He saw inside the structure of myth a binary logic that we also can find in divisive political ideology and universalizing civil discourse alike. The work of Geertz, Turner, and so many other anthropologists provides a mirror with which we can reflect upon the rituals, ceremonies, icons, and theatrical performances that drive our society just as much as rational choices, rules, and infrastructures. Certainly, contemporary societies are immensely different from earlier ones. They are wealthier and more populated, urbanized, filled with fantastic technology, sometimes more democratic. Perhaps they are more cynical too. And they can boast of a differentiated, highly professionalized sphere-science-that is devoted to rationality, measurement, and transparency, and has produced predictive theories of the natural world that allow immense control. But none of this has eliminated the need for meaning, nor the role of those meanings in shaping social outcomes. Nowhere has this been more visible than in the case of COVID-19.

For all the real-world tragedy, COVID-19 will long be prized by social scientists as a "natural experiment." Arriving as an unanticipated exogenous shock, it has offered a unique opportunity to see how components of the social systempublic health, politics, and economics most obviously—might best respond. From the perspective of cultural sociology, the pivotal opportunity for investigation is one of meaning. The emerging COVID-19 outbreak presented a novelty that was

Jeffrey C. Alexander

jeffrey.alexander@yale.edu

Philip Smith

philip.smith@yale.edu

1 Department of Sociology, Yale University, 493 College Street, New Haven, CT 06511-8933, USA 
strange, disruptive, and dangerous. Could society make sense of something entirely unknown, except to the handful of super-centenarians who had witnessed the influenza epidemic in 1918? It turns out the cultural system was up to the cognitive task. Instead of producing a Brownian motion of isolated, jiggling meanings, COVID19 very rapidly generated a set of stable collective representations and so became "thinkable." But most of this social knowledge has not been in the scientific idiomit has been far more primordial. COVID-time has been suffused with mystery, superstition, and trauma; peopled with god-like heroes; generative of myth, new interpersonal rituals, but also iconic circulations of familiar imagery; and it has been haunted by a relentless search for both the blame and the salvation of charismatic authority.

The first few weeks and months were a remarkable demonstration of a societal capacity for highspeed bricolage as familiar structures of meanings (narrative, iconography, genre, binary codes) and meaningful practices (collective rituals, interaction rituals, and performances) were bolted and glued together in new ways. Far from being impotent reflections on reality, these shaped that reality in turn. They influenced public health policy, determined political legitimacy, generated the solidarity that would enable mass lockdown, allowed people to get their work done, and permitted civility to lubricate everyday life. It is clear that we need a cultural sociology to fully understand the social responses to COVID-19. The contributors to this volume begin this task, showing in the process that the existing resources of our academic field have remarkable traction and flexibility. Cultural sociology as we know it is more than a library of clever, one-off interpretations. It has cumulated methodologically, conceptually, and theoretically, and it has cultivated the tacit knowledge required to "do" the job at short notice. The "natural experiment," it turns out, tells us something about the health of our field as well, even as the health of the social world sputters.

One of the most fully developed themes that emerges from the articles that follow is how challenging it has been to create authority in a time of crisis. From a legal-rational perspective, creating political authority should not be a big deal so long as a country's leaders come to power constitutionally. But cultural sociology, especially in the Strong Program idiom, has long shown that symbolic power does not necessarily follow from legal-rational authority. As Marcus Morgan illustrates in his discussion of the response in the United Kingdom, for a government to act effectively, its political leaders need to control the national narrative; they not only want to tell a particular story but to place themselves inside the narrative as iconic characters, as heroic protagonists, as trustworthy. Leaders need extra-rational power. They need to become powerful symbols telling dramatic stories about themselves and others, about how good people can contain COVID, survive the crisis, get healthy, and return to normalcy again-and about how bad people or poor judgments will prevent them from doing so.

In Durkheim's primitive societies, these tasks-of containment, healing, and reestablishing normalcy-were accomplished by "ritual." Rituals are stylized, integrative ceremonies, often of great emotional intensity, that bring a clan together in synchronized, preordained chants, dances, and prayers. Rituals are organized around totems and symbols, and led by elders or shamans with sacred authority who offer 
magical cleansing experiences and divinations to ward off dangerous illness and enemies. Because cultural sociology challenges the idea of a radical break between primitive and modern societies, it is not surprising that, when cultural sociologists study political authority, they tend to think more in terms of "ritual-like" processes than in terms of legality, rational consent, and scientific truth. Of course, mass-mediated and conflictual as well as contingent, rituals today are not what they used to be. Yet, in "Performing Rituals of Affliction: How a Governor's Press Conferences Provided Mediatized Sanctuary in Ohio," Celso M. Villegas finds that the press conferences presided over by Ohio's Republican governor, Mike DeWine, resembled "rituals of affliction" in primitive societies. Press conferences ostensibly are about providing information, but Villegas conceptualizes them, instead, as public stages for dramatic performances. Such dramatic performances can provide "feeling[s] of comfort and stability" during dangerous times. Villegas demonstrates that Governor DeWine came to be regarded as a sacred, non-partisan, healing figure. He gained this status not as the fountainhead of rationality and science but, rather, by appealing to Ohioan myths and legends, like the Midwest as a place where reasonable, pragmatic and responsible people quietly do what has to be done. Embodying the "us" rather than the "they," De Wine and his two high-ranking government associates became revered popular icons, the subjects of songs, videos, comedy routines, and bobblehead dolls. As such, they became "iconic."

In "A Virus as an Icon: The 2020 Pandemic in Images," Julia Sonnevend shows just how central such iconic consciousness has been to the crisis more generally. COVID-19's meanings are not simply narrative and discursive. A repertoire of images has circulated globally, from the artistic rendering of the virus itself to visual representations of human suffering and solidarity, disruption, and danger. As these aesthetic reconstructions of reality became more familiar, they were adapted, fused, and combined into complex systems of allusion and condensation. In this way, a visual language to COVID-19 emerged alongside other recognizable and accountable shifts in language, metaphor, and everyday life.

While this special issue does not include an article about the travails of political performance in the U.S.- - nor, notably, President Trump's tragi-comic inability to become a credible leader in the war against COVID-19-it does include two papers on the twists and turns of collective representation and national political performance in Great Britain, the ultimate failure of which allowed COVID-19 to become more widely spread there than anywhere else in Europe. In "Why Meaning-Making Matters: The Case of the UK Government's COVID-19 Response," Marcus Morgan shows how in the UK-as in the U.S. - political authorities initially responded to COVID-19 with breezy denials. At the root of this was a cultural, not simply political or scientific, process. Drawing on Strong Program theory, Morgan shows that risks are evaluated by means of narrative classification. Making the wrong "genre guess," the British government either ignored science entirely or followed scientific epidemiology in its most radical and inhumane form, embracing the goal of "herd immunity." Such a policy, it was eventually calculated, would require as many as a quarter million deaths before herd immunity could be achieved. By the time British Prime Minister Boris Johnson and his government turned to more sensible and effective measures, crucial time had been wasted. The virus had spread and lives 
would be lost over the coming weeks. Morgan shows that, recognizing the gravity of the situation, government authorities moved on to evoke hallowed national myths about national trauma, courageous war fighting, and sacrifice. There had been a genre shift.

In "Marking Time in Lockdown: Heroization and Ritualization in the UK during the Coronavirus Pandemic," Lisa McCormick also picks up on this imagery. She shows in vivid detail how such metaphors about war and sacrifice circulated powerfully throughout the British nation. She reconstructs the story of Captain (Sir) Tom Moore, the 99-year-old, still spry, former English tank commander. During the early months of the pandemic, Captain Tom became a beloved national hero when, using his walker for support, the soon-to-be centenarian completed 100 laps of his 25-meter garden - an achievement that was broadcast live on national television. Moore was not the only ritual performer. The Queen, NHS health workers, and Prime Minister Johnson were also on stage by late spring. When Johnson called for sacrifice, self-discipline, and heroism, and used a Churchillian turn of phrase, he quickly became a national hero himself. Announcing a national lockdown and other severe measures, Johnson's performances fused with the citizen-audience, generating an extraordinary 93\% approval rating in polls. Yet, just weeks later, the Prime Minister's popularity had crashed, with national solidarity dissolving amidst partisanship and recrimination. How could this have happened? Cultural sociology has the explanation. McCormick points to the sudden absence of the central actor. At the high point of his cultural authority, Boris Johnson contracted the virus and was forced to leave the scene. For the many days of his illness, nobody with performative ability and political authority directed the government's COVID response. But as both Morgan and McCormick point out, not just Johnson's absence but his incompetence was at issue. After he regained his health, there unfolded a series of highly publicized breakdowns in governmental planning, failures in the public health system, episodes of gross mismanagement, and a scandal suggesting that there was one quarantine rule for the powerful and another for the rest of us. The war narrative was now turned against political authority. Only some people were making the necessary sacrifices.

In Western societies like the UK (and the U.S.), it has been difficult for political leaders to generate powerful political authority. Even when they have had it, their "genre guess" has made them reluctant to risk it by mounting the ambitious, maximally intrusive anti-COVID campaigns that their scientists advised. But what of non-Western contexts? How about China? Its powerful party-state eventually succeeded in taming COVID with harsh social policies introduced quite early. In 'The 'Societalization' of Pandemic Unpreparedness: Lessons from Taiwan's COVID Response," Ming-Ching M. Lo and Hsin-Yi Hsieh write that China's powerful recovery has led some observers to believe only authoritarian governments can control pandemics. Such states do not have to rely on cultural power and collective solidarity. A party-state, they write, has the "capacity for enforcing top-down commands, controlling the media, and ensuring public compliance." This narrative about what Lo and Hsieh call "authoritarian advantage" has been promoted by the Chinese government itself: "[T]he distinguishing contrast between China's success and America's failure has emerged as a dominant COVID-19 narrative in the media." Lo 
and Hsieh counter this line of argument. Democratic Taiwan has a population of 23 million, but, at the time of writing, suffered only 7 COVID deaths and fewer than 500 confirmed cases. It lifted most social distancing requirements on June 7 after recording zero domestically transmitted cases for 56 consecutive days. Taiwan's success, Lo and Hsieh suggest, demonstrates that democratic nations can do as well, or even better, than authoritarian ones-if the conditions are right. What are the conditions? The most basic one is establishing social solidarity. If the dominant social narrative highlights social cooperation over partisanship, then the pandemic will be met with a spirit of generosity and mutual concern, and rational government measures will be widely followed. If such conditions existed in Taiwan in 2020, Lo and Hsieh demonstrate, it was because of lessons the nation had learned in 2003 from the SARS epidemic. Taiwan's response to SARS was widely acknowledged to have been the worst in Asia. Medical staff refused to expose themselves to sick patients; companies and governments were unable to produce and supply PPE (personal protective equipment); and political parties feuded while citizens died. The SARS experience humiliated Taiwan, creating a cultural trauma that threatened its national identity as a modern, independent, democratic nation. The trauma inspired a deep series of reforms that "societalized" Taiwan's pandemic response system, guaranteeing that next time national solidarity and social trust would prevail. When COVID arrived, not only these newly reformed institutions but the "memory of trauma" quickly came into play.

What transpired in Taiwan between 2003 and 2020 provides a cultural-sociological road map of how the bitter taste of national failure can create social resources for future success-how, from lemons, a society can make lemonade. Societalization explosively illuminates institutional failures, defining them as existential threats to societal solidarity and allowing civil repairs to be made. In "COVID-19 as Cultural Trauma," Nicolas Demertzis and Ron Eyerman argue that what triggers such a process is the experience of collective trauma, the excruciating sensation that a crisis threatens the heart of society, undermining the collective identity that sustains its very existence. Observing that the traumatic experience of COVID-19 was not only intense but immediate and world-wide, Demertzis and Eyerman develop the concept of "compressed cultural trauma," a trauma that mirrors the time-space compression of late-modern globality. Yet, even as people around the world shared the same sharp and debilitating "loss of existential security," contentious meaning struggles unfolded about how to narrate such traumatic experience. Who were the perpetrators? Who the victims? "Public discourse about the coronavirus and its effects," they write, was "multifaceted, antagonistic, and replete with emotionality." In their analysis of how the global crisis played out in Sweden and Greece, they emphasize-like Lo and Hsieh - the formative significance of earlier experience (path dependency) alongside the contingent ability of authoritative performances to generate social trust in the present day. Putting their faith in politically sanctified scientific authorities, Greeks and Swedes closely followed sharply divergent health directives. In Greece, such responsiveness caused great, if temporary, national sacrifice; in Sweden, it did not. In contrast with Greece, Sweden had not experienced a national trauma for centuries, and it was determined not to let COVID-19 trigger one. Swedish authorities argued that the nation faced a severe public health crisis 
rather than a crisis of national identity, and Swedish citizens believed them. This fusion of leaders with citizen-audience avoided a national shutdown, although it led to an unprecedented loss of life among Swedish seniors.

In "The Performance of Truth: Politicians, Fact-Checking Journalism, and the Struggle to Tackle COVID-19 Misinformation," María Luengo and David GarcíaMarín complicate the idea that, if public authorities act felicitously, their performances will succeed and their authority to impose public health measures will be sustained. In contentious and polarized democracies, what seem to one side to be realistic statements of fact are immediately polluted, by the other side, as cynical distortions that serve irrational ideologies. Such tit-for-tat has accelerated with social media, and has led to pessimistic assessments of a "post-factual world." Luengo and García-Marín observe, to the contrary, that the effect of such intensifying circles of relativizing accusation has actually been the creation of the new institution of "fact-checking." The binary code truth-versus-lies has long been central to the cultural construction of civil society. Indeed, relatively autonomous civil spheres contain a critical communicative institution-journalism-dedicated to providing accurate accounts of social events as they unfold. Luengo and García-Marín show that fact-checking institutions have emerged from within professional journalism. Providing a new form of "interpretive power" that stands between political performers and citizen-audience, the independent fact-checking of public statements-about the coronavirus and health policies - has been critical to sustaining, or undermining, efforts of political power to establish cultural authority.

With the exception of Ohio, we have been looking here at the national level—at the large-scale cultural processes through which COVID-19 has been managed. But, of course, COVID-19 presents a fractal challenge requiring cultural responses at all levels. The slogan "alone together" suggests a common experience. Is this more national myth than daily reality? Impacts, solutions, and meanings vary across lifeworlds. This is nicely illustrated in "Art Markets in Crisis: How Personal Bonds and Market Subcultures Mediate the Effects of COVID-19” by Larissa Buchholz, Gary Alan Fine, and Hannah Wohl. Artists, dealers, and auction houses form a network that runs on trust and is fueled by enthusiasm. Art, after all, is only worth what someone will pay for it, and someone has to pay something if there is going to be a "market." The required trust and enthusiasm are routinely generated by interpersonal meetings, by gallery opening parties, and by the drama of the auction room. COVID-19 disrupted all this. In-person meetings and viewings became difficult. The dynamics of production and exchange had to be revised. Artists looked for inspiration in new directions. Dealers and artists communicated online. Auctions were live-streamed. Because of such social innovations, the artworld struggled on, and regained some momentum.

Whether this would be viable in the long term is not so clear. Consider the contribution of Randall Collins in "Social Distancing as a Critical Test of the MicroSociology of Solidarity." We mentioned earlier that COVID-19 was a natural experiment. Collins makes this property central to his thinking. By generating a world in which familiar, embodied, in-person interaction was suddenly no longer possible, the health crisis enabled Collins to test his influential theories about interaction ritual and emotional energy. Collins draws on a range of data to demonstrate 
that online encounters have not been so satisfying after all-that, without interaction rituals, civic solidarity has had a short half-life. Life under COVID has been deeply frustrating, Collins concludes, because people cannot generate the meaningful encounters they need. Notwithstanding pundits who talk about social life moving online, he suggests this is clearly something people do not want. Being with others matters for mental health, for educational outcomes, and for having fun.

As we write, COVID looks set to be with us for a while to come. The initial period of shock, interpretation, and cultural adaptation documented in these pages has come to an end. Before a vaccine is found, we will likely be entering a new phase in which the threat is increasingly routinized, managed, and taken for granted even as it fluctuates. We have reached the end of the beginning. New conventions, rituals, images, and narratives will no doubt emerge, so there will be more work for cultural sociology before we get to the beginning of the end.

Publisher's Note Springer Nature remains neutral with regard to jurisdictional claims in published maps and institutional affiliations.

Jeffrey C. Alexander, Lillian Chavenson Saden Professor of Sociology at Yale University, co-directs Yale's Center for Cultural Sociology and co-edits the American Journal of Cultural Sociology. Among his recent publications are: "Civil Sphere and Transitions to Peace: Cultural Trauma and Civil Repair" (Int J Polit Cult Soc, 2020 ) and "The Double-Whammy Trauma: Narrative and Counter-Narrative in COVID-Floyd" (Thesis Eleven, 9 July 2020). With Peter Kivisto and Giuseppe Sciortino, he has edited Populism in the Civil Sphere (Polity, forthcoming).

Philip Smith is Professor of Sociology at Yale University and founding co-editor of the American Journal of Cultural Sociology. He has written widely in the fields of cultural sociology and social theory. His books most relevant to this special issue consider themes of risk communication and representation in public life: Why War? (Chicago 2005) and Climate Change as Social Drama (with N. Howe, Cambridge 2015). His most recent volume looks at the past century or so of the Durkheimian tradition: After Durkheim (Polity 2020). 